\title{
What are political parties doing on TikTok? The Spanish case
}

\author{
Laura Cervi; Carles Marín-Lladó
}

How to cite this article:

Cervi, Laura; Marín-Lladó, Carles (2021). "What are political parties doing on TikTok? The Spanish case". Profesional de la información, v. 30, n. 4, e300403.

https://doi.org/10.3145/epi.2021.jul.03

Manuscript received on $12^{\text {th }}$ March 2021 Accepted on $26^{\text {th }}$ May 2021

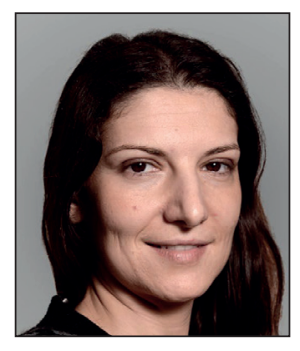

\author{
Laura Cervi $\bowtie$ \\ https://orcid.org/0000-0002-0376-0609 \\ Universitat Autònoma de Barcelona \\ Dept. of Journalism and Communication \\ Sciences, Serra-Húnter professor \\ Carrer de la Vinya, 738 \\ 08193 Cerdanyola del Vallès \\ (Barcelona), Spain \\ laura.cervi@uab.cat
}

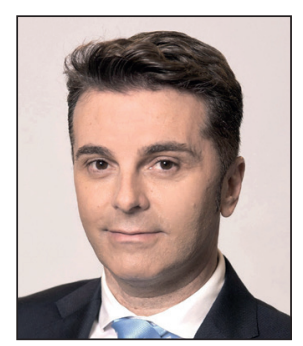

Carles Marín-Lladó

https://orcid.org/0000-0001-7456-5889

Universidad Rey Juan Carlos

Facultad de Ciencias de la Comunicación

Camino del Molino, 5

28943 Fuenlabrada (Madrid), Spain

carles.marin@urjc.es

\begin{abstract}
TikTok, already widely used before the pandemic, boomed during the quarantine that locked down large parts of the world, reaching 2 billion downloads and 800 million monthly active users worldwide by the end of 2020. Of these 800 million users, $41 \%$ are aged between 16 and 24 years. This social network, widely known for its entertainment videos, is increasingly becoming a place for political discussion and therefore a unique opportunity for political actors to (re) connect with young people. Acknowledging that the political uses of TikTok are still understudied, this paper aims to explore whether and how Spanish political parties are including TikTok as part of their communication strategy. Through an affordance-centered content analysis of all the posts published by the five most important Spanish political parties ( $P P, P S O E$, Ciudadanos, Podemos, and Vox), the current results show that, although all Spanish political parties have adopted this platform, their usage is unequal. From a quantitative perspective, $P P$ was the first party to open a TikTok account, but its usage has been discontinuous; Podemos and Ciudadanos are the parties that publish the most and most constantly, while Vox has only published nine posts and the PSOE one. Nonetheless, from a qualitative perspective, Podemos and Vox generate more engagement and seem to understand and exploit TikTok's specific affordances better. The findings allow it to be concluded that, although globally Spanish political parties do not fully exploit the platform's affordances and tend to use it as a unilateral tool for promotion, the most engaging posts are those favoring interaction and geared toward politainment.
\end{abstract}

\section{Keywords}

Political communication; Politics 2.0; Social networks; Social media; Affordances; Interaction; Politainment; Engagement; Political parties; TikTok; Spain.

\section{Introduction}

Most Western democracies are facing declining interest in politics and decreasing party membership, especially among young people (Ekström; Sveningsson, 2019; Moeller et al., 2014). To revitalize their relationship with citizens, political parties have turned to the potential of new media (Bimber, 2014).

While most scholarly attention has focused on Twitter and Facebook, politics 2.0 goes far behind these platforms (Piñeiro-Otero; Martínez-Rolán, 2020).

In particular, to get closer to young citizens, politicians need to be attentive to new successful platforms, where digital natives represent the majority of the audience (Bossetta, 2018): accordingly, after emerging on Instagram or Snapchat, politicians are currently turning their attention to the newest platforms, such as Twitch.

In October 2020, for example, Alexandria Ocasio-Cortez, already well known for answering constituents' questions on Instagram Live and inviting her followers to visit her Animal Crossing island, made her Twitch debut, becoming one of the platform's most important broadcasters (Kastrenakes, 2020). In Spain, two political parties, Más Madrid and Vox, have already opened a Twitch account (Barrio, 2021). 
Along these same lines, TikTok represents a unique opportunity to (re)connect with young people.

This social network, already widely used before the pandemic, has boomed during the lockdown that confined large parts of the world, reaching 2 billion downloads and 800 million monthly active users by the end of 2020 (Omnicore, 2020). Out of these 800 million users, $41 \%$ are aged between 16 and 24 years. The remaining $59 \%$ are not exclusively aged over 24 years as they may also be aged younger than 15 years (Omnicore, 2020).

Although the app is known worldwide for its famous "silly dances" (Vijay; Gekker, 2021) and officially does not allow the publication of political ads, political and nonpolitical uses cannot be fully separated on TikTok. In other words, as Nahon (2016) points out, "where there is social media there is politics". Accordingly, various studies (Medina-Serrano; Papakyriakopoulos; Hegelich, 2020; Literat; Kligler-Vilenchik, 2019) have already shown that politics has a strong presence on TikTok.

TikTok has been a locus for political discussion during the recent US elections (Medina-Serrano; Papakyriakopoulos; Hegelich, 2020) and instrumental in the campaign of Narendra Modi in India (Mirchandani, 2020) and Jair Bolsonaro in Brazil (Cesarino, 2020). In Europe, various politicians, such as French President Macron or, most notably, Italy's former Deputy Prime Minister Matteo Salvini, have successfully started using this platform (Bianchi, 2020).

However, the "political" element of TikTok remains unexplored in academic research.

TikTok's political usage in Spain has attracted wide media attention (see, for example, Cid, 2020), but no academic study has tackled this topic yet.

Accordingly, this paper aims to explore whether and how Spanish political parties include TikTok as part of their communication strategy.

In this vein, it is important to underline that many countries are currently in the process of banning or threatening to ban the app (Koleson, 2020; Zhu, 2020), so its future seems uncertain. However, considering that present trends in usage rates suggest that the short-video format is the future of social media (Piñeiro-Otero; Martínez-Rolán, 2020), it can be assumed that TikTok may probably be the first platform to remix and combine previously disparate affordances but that it will not be the last (Guinaudeau; Vottax; Munger, 2020). Therefore, regardless of whether the platform will continue to exist and grow or whether it will be banned worldwide, it is still worth analyzing (Anderson, 2020) to reflect on this new communication scenario.

\section{Theoretical background}

Since the US elections of 2008, marked by Barack Obama's innovative use of social networks, their influence on political communication has continued to grow in all advanced democracies (Bimber, 2014).

In the current hypermediated context (Chadwick, 2017), politics operates in a mode of "permanent campaign" (Blumenthal, 1980): politicians and political parties need to communicate constantly, during both campaigns and routine periods (Vasko; Trilling, 2019). Social media platforms, in this regard, offer a cheaper and quicker alternative to traditional media tools.

Social media's disintermediated nature provides the chance to bypass media gatekeepers, communicating directly with citizens (Dolezal, 2015; Manfredi-Sánchez; Amado-Suárez; Waisbord, 2021). This direct communication, building on tailor-made strategies (Quinlan et al., 2018; Enli; Naper, 2016) and microtargeting (Zarouali et al., 2020), allows the establishment of almost personal relationships with citizens, enhancing the interaction between the public and politicians (Dimitrova; Matthes, 2018).

However, current research has shown that the adoption of social media by politicians and political parties is far from uniform (Gainous; Wagner, 2014). On the one hand, young politicians seem more prone to integrate social media into their global communication strategies (Dimitrova; Matthes, 2018; Dolezal, 2015), while on the other, challenger and underdog parties, which normally have less resources at their disposal and more urgency for promotion, tend to opt for social media more than established parties (Kreiss; Lawrence; McGregor, 2018; Stier et al., 2018; Jungherr, 2016).

In this vein, a wide stream of research has identified the use of social networks by populist parties as one of the keys to their current success, to the extent of defining the relationship between social media and populism as an "elective affinity" (Gerbaudo, 2018), which can be seen as a precondition for the rise of a new family of "technopopulist" parties that cannot be understood without comprehending their interaction with social media (Bickerton; Invernizzi-Accetti, 2018).

This social media disintermediation happens to be especially important for populists to circumvent hostile journalistic gatekeeping (Groshek; Engelbert, 2013), while also representing an ideal anti-elitist "discursive opportunity" (Koopmans; Statham, 2010) to frame mainstream media as part of the corrupt "elite." Moreover, social media's attention 
economy, which favors simple content (Klinger; Svensson, 2016) and emotional communication (Papacharissi, 2015), runs counter to the key traits of establishment politics, such as formality and moderation (Gerbaudo, 2018), providing a perfect match with populists' discursive dynamics, with an emphasis on emotional elements (Hopster, 2020) and a simplified, dichotomous vision of the world (Enli; Rosenberg, 2018).

\subsection{Social media and politics in Spain}

A wide stream of research has studied the usage of social networks by both politicians and political parties in Spain.

Most studies have focused on Twitter (the most recent including Abuín-Vences; García-Rosales, 2020; Suau-Gomila, 2020; Suau-Gomila; Pont-Sorribes, 2019) and/or Facebook (López-Meri; Marcos-García; Casero-Ripollés, 2020; Abejón-Mendoza; Carrasco-Polaino; Garralón, 2019).

Although most of these works analyzed content rather than interactions, they seem to agree in concluding that, in general, Spanish political parties do not seem to be taking full advantage of the opportunities that social networks offer to establish a renewed interaction with citizens (Suau-Gomila, 2020). Rather, most parties use these platforms as unidirectional channels of promotion (García-Ortega; Zugasti-Azagra, 2018); that is, they tend to reproduce the old model of political discourse with low levels of political engagement (Miquel-Segarra; López-Meri; Viounnikoff-Benet, 2020).

In particular and in parallel with findings in other contexts, this literature distinguishes between "old," established and "new," entrepreneurial parties, with the latter being more prone to use social media (López-Meri; Marcos-García; Casero-Ripollés, 2017). Besides, these studies outline that, while established parties tend to appeal to the logic of persuasion, explicitly calling for votes, entrepreneurial parties, in particular, Podemos, focus more on mobilizing their supporters (Cervi, Laura; Roca-Trenchs, 2017b; 2018).

Moreover, social networks tend to create a more personalized environment in which individual politicians are profiled independently from their political party (Metz; Kruikemeier; Lecheler, 2020).

International scholars have documented a trend towards more personalized communication patterns on social media (Vergeer; Hermans; Sams, 2013), while in Spain this trend does not appear clear. López-Meri et al. (2017) studied the use of Twitter during the 2016 campaign and found low degrees of personalization of politics, while Jivkova-Semova, Requeijo-Rey, and Padilla-Castillo (2017) analyzed the use of the same network during the previous campaign and concluded that personalization and intimization are key traits of political usage of Twitter, being geared toward infotainment.

Although less numerous, some studies have reported the commitment of political parties to approach younger public using Instagram (Pineda; Bellido-Pérez; Barragán-Romero, 2020; Turnbull-Dugarte, 2019; Selva-Ruiz; Caro-Castaño, 2017), YouTube (Gil-Ramírez; Gómez-de-Travesedo-Rojas, 2020; Berrocal-Gonzalo; Campos-Domínguez; Redondo-García, 2014), and Snapchat (Gutiérrez-Rubí; Peytibi, 2016).

This stream of work seems to agree with the former in distinguishing between the social media adaptation of "old" and "new" parties. For instance, Turnbull-Dugarte (2019) and Selva-Ruiz and Caro-Castaño (2017) studied Instagram and agree that the use and level of engagement of Podemos and Ciudadanos are significantly higher compared with traditional, mainstream parties. However, Ramírez-Gil and Gómez-de-Travesedo-Rojas (2020), focusing on YouTube, showed how politicians seem unable to fully exploit all the possibilities of audiovisual language, openly identifying Spanish parties' adaptation to new social media platforms as an "unfinished business."

This growing body of research sheds light on interesting aspects but focuses primarily on election campaigns. Acknowledging that politicians permanently campaign for support from the electorate and that social media provide an infrastructure for this (Larsson, 2016), as suggested by Casero-Ripollés (2018), we turn our attention to nonelection periods.

In addition, as pointed out by Bucher and Helmond (2018), there is a general trend to treat social media as "one," that is, to draw general conclusions about social media while adoption, ignoring, or not giving sufficient importance to the specific features of each platform.

\subsection{Social media affordances}

The concept of affordance describes how objects provide possibilities for action (Zheng; Yu, 2016). Recognizing that the architecture of each social medium is different (Nahon, 2016) in terms of its structural design, functionalities, algorithms, and datafication models (Van-Dijck; Poell, 2013) and that digital architecture affects human behavior (Bossetta, 2018), one can assume that technical protocols shape user behavior in virtual spaces.

In other words, each social medium is a unique sociotechnological environment, offering particular affordances that shape the dynamics of communicative practices and social interactions (Bucher; Helmond, 2018).

The adoption of social media by politicians and political parties is far from uniform. On the one hand, young politicians seem more prone to integrate social media into their global communication strategies, while on the other, challengers and underdog parties, which normally have less resources and more urgency for promotion, tend to opt for social media more than established parties 
Accordingly, to successfully adapt to social media platforms that are characterized by different functionalities and algorithms (Kreiss; Lawrence; McGregor, 2018) and thus different audiences and structural affordances, political actors must fully comprehend them, especially in terms of the norms regarding appropriate content and interactions. If they fail to understand these, they run the risk of being perceived as out of touch, inauthentic, or out of place (Baldwin-Philippi, 2015).

Before proceeding, it is thus seminal to understand TikTok's specific affordances.

\subsection{TikTok's affordances}

Originally born as a lip-syncing app, TikTok is a social network aimed at creating and sharing short-form (15-30 seconds) mobile videos, which mainly take the form of lip-syncing, acting out, or dancing to songs or dialogs (Vijay; Gekker, 2021).

According to the app itself, its main mission is "to inspire creativity and bring joy" (TikTok, 2020), creating a community for entertainment that revolves around granting immediate gratification (Cervi, 2021).

Users can choose from a wide selection of music and myriad easy-to-use professional filters and editing services (including augmented reality) to create their videos.

However, what makes the platform distinct is the possibility for replication and virality (Vijay; Gekker, 2021) as every TikTok video has the potential to prompt the creation of another video.

In this sense, the two main genres (Kennedy, 2020) on the platform are "Duet" and "Challenge." Duets are based on users' taking a video of another person and adding themselves performing the same action, scene, or choreography. Challenges are (often sponsored) community-created hashtags, in which tiktokers are invited to create videos showing themselves attempting to do a certain action/dance/trick proposed by others.

Probably the most interesting feature of TikTok is its algorithmic recommendation system, which is more central to the user experience than for any other platform (Vijay; Gekker, 2021; Guinaudeau; Vottax; Munger, 2020).

Users' interests and preferences are analyzed through their interactions with content, based on videos they "like" or comment on and how long they watch them, to construct a personalized content feed for each user. In other words, instead of being based on connections, or "people you know," like other social networks, the TikTok algorithm provides personalized information flows through the "For You" page, a feed of videos that are recommended to users based on their activity on the app.

It appears, therefore, that algorithms control what users see on TikTok to a greater extent than on other platforms (Vijay; Gekker, 2021); in addition, although further study is needed, recent research (Simpson; Semaan, 2021) has shown that users tend to spend more time on the "For You" page rather than actively looking for content.

\section{Objectives}

As mentioned above, the political usage of TikTok is still understudied. No previous work has systematically analyzed the use of TikTok by political parties in Spain or elsewhere, which is the novelty of this study.

Accordingly, its general aim is to explore how political parties use TikTok, shedding light on the Spanish case, while also offering a methodological framework to analyze the political use of this platform for future studies.

Our analysis aims to answer the following research questions:

1. Do the main Spanish political parties use TikTok as part of their communication strategy?

2. Following an affordance-based approach (Bucher; Helmond, 2018), how well do they adopt and adapt to TikTok's main affordances? What kind of content do they share?

3. What kind of interaction with users do the main Spanish political parties promote on TikTok?

Along these lines, the paper also explores which posts create higher levels of engagement with TikTok users.

\section{Hypotheses}

The absence of previous specific literature on TikTok prevents the formulation of specific hypotheses, but considering previous findings on other platforms, we might expect that:

H1. Acknowledging the importance of social media, and especially those targeting young people, all the parties will integrate TikTok into their communication strategy.

H2. Parties that show more activity on other platforms will show a higher degree of activity on TikTok.

In this regard, considering previous studies (in particular, López-Meri; Marcos-García; Casero-Ripollés, 2017), we can expect Podemos and Ciudadanos to show higher degrees of activity.

Also, we might expect Vox to be more active than established parties, considering its nature as an entrepreneurial party and the results of recent studies (Sampietro; Sánchez-Castillo, 2020), although this has been understudied because of its newness. 
H3. Considering the "elective affinity" (Gerbaudo, 2018) between social media and populism, we expect populist parties, in this case Vox and Podemos, to engage more. Podemos in particular, as part of the "technopopulist" party family (Bickerton; Invernizzi-Accetti, 2018), should show higher degrees of interactivity.

\section{Methods}

The parties considered are the five most voted-for parties in Spain's last general elections of 10 November 2019, together accounting for more than $80 \%$ of the votes. The selection includes two traditional parties, the Partido Popular $(P P)$ and the Partido Socialista Obrero Español (PSOE), the two (already established) challenger parties, Ciudadanos and Podemos, and the newcomer, Vox, that entered Spanish politics and joined the Congress of Deputies for the first time in the general elections of April 2019, currently having 52 seats (Cervi, 2020).

In this regard, it is important to underline Podemos's change of status: after entering the government in 2020 via the coalition Unidas Podemos, this party can no longer be considered a challenger.

Each party's official TikTok account is considered. In this sense, it is interesting to note that only Vox displays a link to their TikTok account on the party's web page.

Given TikTok's recent adoption by political parties and the overall small $N(172)$, all the posts published by the selected parties were analyzed, so this analysis includes the total population of posts made by each party up to the date of data collection (30 October 2020). The analyzed timeframe (28 March 2019 to 30 October 2020) thus includes both routine and election periods.

Unlike other social media platforms such as Twitter and YouTube, TikTok does not provide a commercial application programming interface (API) to share data on users and their behavior, so data (posts, number of followers, number of "likes," comments, and shares) were collected manually by the authors.

This research combines quantitative and qualitative content analyses. The unit of analysis is posts, defined as both video content and the accompanying caption provided by the party (but excluding the content of comments).

The content of each post was coded by two coders using a spreadsheet built on a variety of indicators, including formal criteria and content-related characteristics.

The coding frame consisted of a series of dichotomous questions with a yes/no response, assigned empirical values of $1 / 0$ to enable data processing by SPSS. This method, based on a proposal by Vergeer, Hermans, and Cunha (2009) and applied, among others, by Cervi and Roca-Trenchs (2017a), enables the measurement of each category empirically and thereby their comparison.

The formal criteria included the coder identification number, post identification number, party, and publishing date of the post.

The analytical variables were constructed through a combination of categories used in previous work and applied to other social networks and original categories, based on the specific affordances of TikTok.

The first part (Table 1) is dedicated to specific affordances of TikTok and aims to understand whether parties have adapted to TikTok's main genres and exploit all the technical possibilities offered by the platform in creating their videos.

In addition, the sources of the videos are considered, distinguishing among original "party content" (created specifically for TikTok or coming from other social media), "media" (content derived from media extracts such as interviews and media appearances), or content from other users (when a party shares content from other tiktokers).

The second part is dedicated to the content, differentiating among political, personal, and entertainment content.

Under political content, we coded all the explicitly political videos by identifying two main frames ("issue frame" and "game frame") to deepen the understanding of the political strategy, thus following and adapting the typologies used by Aalberg, Strömbäck and De-Vreese (2012) and Alonso-Muñoz and Casero-Ripollés (2018) among others.

Posts focusing on political issues, and positions on specific issues (Dekavalla, 2018), were coded as the "issue frame," whereas posts centering on political tactics or strategy, presenting the political arena as a power game or battle, were coded as the game frame.

Within the game frame, we also coded the frequency of messages geared towards celebrating the party's results and those geared towards attacking adversaries.

Moreover, although many authors include personalization as part of the game frame (López-Meri; Marcos-García; Casero-Ripollés, 2020), this study, in accordance with Metz, Kruikemeier, and Lecheler (2020), adopts the theoretical conceptualization of Van-Aelst, Sheafer, and Stanyer (2012) in recognizing that personalization is a multilayered concept.
Each social media platform is a unique socio-technological environment, displaying particular affordances that shape its dynamics of communicative practices and social interactions 
Accordingly, within the game frame, to be able to measure the relative importance given to parties and individual politicians, we distinguished between personalization and political branding, where the former corresponds to the original meaning of the term focusing on individual politicians at the expense of political parties and institutions (Rahat; Sheafer, 2007).

In other words and following Metz, Kruikemeier, and Lecheler (2020), we coded "professional personalization" within this category, i.e., targeting the qualities and individual activities related to the official role, rather than "private personalization," which can be defined as personal information about the private persona.

Under "political branding," on the other hand, we coded messages regarding the party (about the party and its logo or corporate image).

Thus, aligning with Metz, Kruikemeier, and Lecheler (2020), we coded messages related to "private personalization," that is, presenting politicians as private personae, their personal life (family and hobbies), or their life outside their political role, under the category of "personal content." This type of personal content appears to match the specific affordances of TikTok particularly well, as most of the videos are homemade and depict personal life (Kennedy, 2020).

Finally, the "entertainment" category collects all the videos that have no relation with politics and are displayed just for "fun" (dances, jokes, etc.), constituting the main genre of TikTok as mentioned above.

On another level, to determine whether parties communicate with the electorate hierarchically or horizontally and which type of interaction they favor, the three levels of interaction proposed by Lilleker and Vedel (2013) were adapted. Lilleker and Vedel (2013) consider that three levels of interaction are possible:

- the first and most basic is information/promotion, whereby political parties use social networks substantially as an "old" means of conveying information, without promoting any type of interaction with others;

- at the intermediate level we find deliberation or discussion, at which, as the definition suggests, the party promotes a bilateral exchange of opinions through a more or less open request for feedback;

- and finally, at the highest level, we find "mobilization," in which parties openly encourage citizens to participate by sharing or creating content, taking part in events, etc.

Accordingly, posts displaying unilateral communication, where users are passive spectators, were coded as "information/promotion." Posts in which parties ask for people's opinions were coded as "deliberation/discussion," and posts containing explicit requests for action to be taken by users, including suggestions to follow the party (or other accounts associated with the party on additional media platforms), opportunities to attend an event, or to create their own content, were coded as "mobilization."

Table 1. Categories of analysis

\begin{tabular}{|c|c|c|c|c|c|c|}
\hline \multicolumn{7}{|l|}{ Genre } \\
\hline \multicolumn{3}{|l|}{ Video } & \multicolumn{2}{|l|}{ Duet } & \multicolumn{2}{|l|}{ Challenge } \\
\hline \multicolumn{7}{|l|}{ Format } \\
\hline Only video & $\begin{array}{l}\text { Video with } \\
\text { effects }\end{array}$ & Video with music & Video and text & Video with effects and music & $\begin{array}{l}\text { Video with } \\
\text { effects and text }\end{array}$ & $\begin{array}{l}\text { Video with effects, } \\
\text { text, and music }\end{array}$ \\
\hline \multicolumn{7}{|l|}{ Source } \\
\hline \multicolumn{3}{|l|}{ Party } & \multirow{2}{*}{\multicolumn{2}{|c|}{ Media }} & \multirow{2}{*}{\multicolumn{2}{|c|}{ Users }} \\
\hline Original & \multicolumn{2}{|c|}{ Other social network } & & & & \\
\hline \multicolumn{7}{|l|}{ Content } \\
\hline \multicolumn{3}{|l|}{ Political } & \multicolumn{2}{|r|}{ Personal } & \multicolumn{2}{|c|}{ Entertainment } \\
\hline \multicolumn{3}{|l|}{ Issue frame } & & & & \\
\hline \multirow{4}{*}{ Game frame } & \multicolumn{2}{|c|}{ Political branding (party) } & & & & \\
\hline & \multicolumn{2}{|c|}{ Personalization (leader) } & & & & \\
\hline & \multicolumn{2}{|l|}{ Praising } & & & & \\
\hline & \multicolumn{2}{|l|}{ Attacking } & & & & \\
\hline \multicolumn{7}{|l|}{ Interaction } \\
\hline \multicolumn{3}{|c|}{ (1) Information and promotion } & \multicolumn{2}{|c|}{ (2) Deliberation and discussion } & \multicolumn{2}{|c|}{ (3) Participation and mobilization } \\
\hline
\end{tabular}

Following O'Connor and Joffe (2020), a first intercoder reliability test was implemented on a subset of the data (10\%) to identify codes that required refinement. The final intercoder reliability test, applied to the full dataset, met the kappa > 0.80 standard for all the variables (Cohen, 1960).

Finally, we measured the engagement rate and looked for the most engaging posts to understand what favors engagement. 


\section{Results}

As shown in Graph 1, the Partido Popular was the first party to join TikTok, in March 2019, followed by Podemos in January 2020, Vox in February, Ciudadanos in March, and the PSOE in June of the same year.

Podemos, with a total of 94 posts, is the party that published most and most constantly, followed by Ciudadanos. The PP started using the app but then left it. The PSOE only published one time, and Vox nine times.

Regarding the TikTok genres, it was observed that the political parties hardly use "challenges" or "duets". Only Podemos published one duet with a user and one challenge. The other parties do not display content in these categories (except for the $P P$, which published one challenge).

In this sense, it is clear that the parties do not fully exploit TikTok's affordances.

From a format perspective, on the other hand, they tend to use all the facilities offered by the platform. An average of $95 \%$ of the posts of all the parties show usage of all the effects that the platform offers.

Regarding the sources, as shown in Graph 3 , most of the videos correspond to content created by the party, followed by the distribution of content from other media.

In this regard, it is interesting to observe how only Podemos, Vox, and PSOE (in its only post) broadcast content originally produced for this platform.

The PP mainly distributes party-produced content (advertising and political branding), also seen on other platforms, while $80 \%$ of the content shared by Ciudadanos is composed of media extracts.

Most of the parties mainly distribute extracts of their parliamentary activity, while Podemos and Vox are the only parties to share content created by other users.

From a content perspective, as shown in Graph 4 , an overwhelming majority of the content broadcasted on the platform is political: Podemos, Ciudadanos, and PP post some entertainment content, while only Podemos, and in a very limited way, shows the personal life of politicians.

It is thus clear that TikTok is used by all the parties as a medium to talk about politics, without any interest in the personal life of political actors.

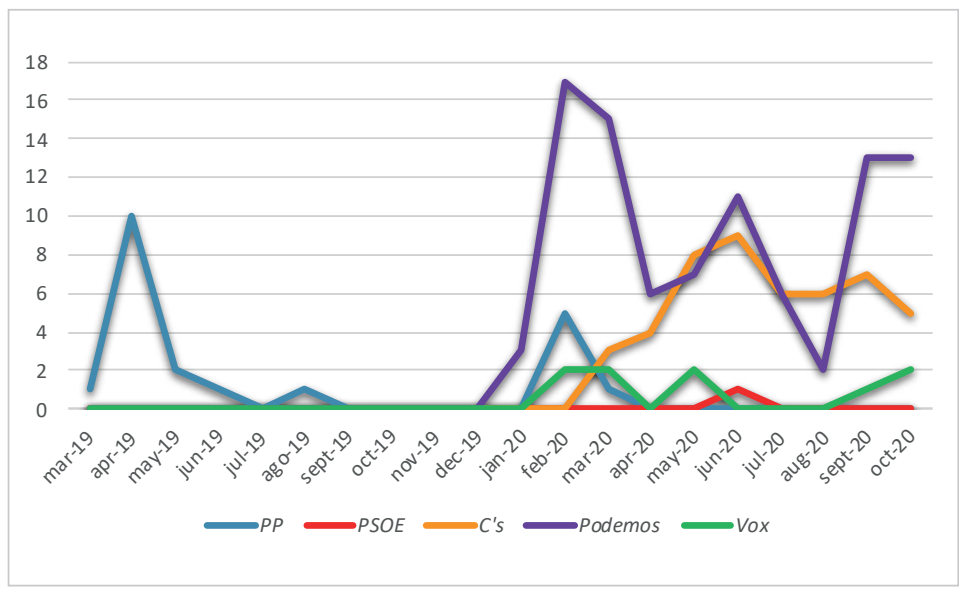

Graph 1. Evolution of TikTok usage

Table 2. Date and number of posts per party

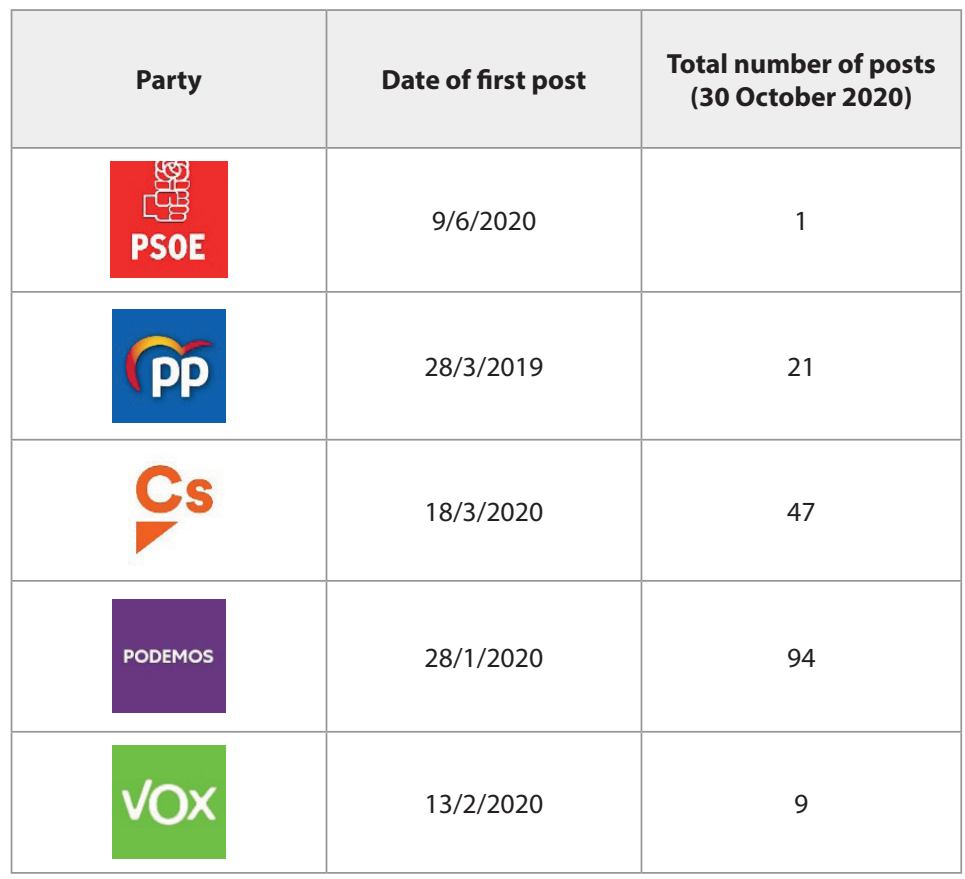

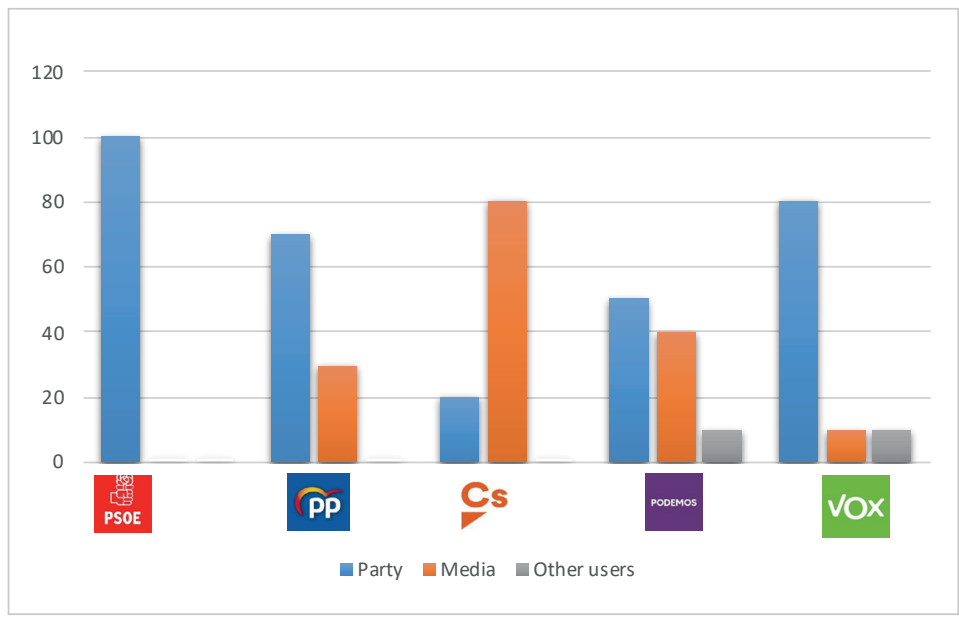

Graph 2. Main sources of posts 
The main content is thus political, mainly being presented in the game frame. The PSOE and Vox uniquely publish content representing politics as a battle, while the great majority of the content from the other parties is in this category.

Of the content posted by Podemos, $35 \%$ is dedicated to political issues, followed by Ciudadanos with $30 \%$ and the PP with $10 \%$.

In particular, the majority of the issue-based content posted by Podemos is concentrated during the early months of the coronavirus disease 2019 (Covid-19) pandemic and basically comprises public health suggestions.

Within this broad game frame, as shown in Graph 6, the PSOE (whose only post was dedicated to attacking adversaries) and Ciudadanos exhibit a great majority of messages attacking other parties, a trend followed by Vox, while the $P P$ shows a balanced mix between messages that praise the party and messages that attack competitors. Only Podemos displays a majority of posts that praise the party rather than attacking competitors. While for the other parties such attacks are generally directed towards all the adversaries, Podemos mainly targets Vox.

Politics, in other words, is mainly represented as a polarized battlefield, in which, for most of the parties, attacking opponents is more important than stressing goals.

Regarding personalization, many differences can be observed. The PP and Ciudadanos clearly put the party at the center: Ciudadanos almost always (95\%) publishes their activity in the Congress, without any emphasis on the leader, while most of the $P P^{\prime}$ 's posts are geared towards political branding, with the party logo being more important than any political actor.

On the other hand, both Podemos and Vox tend to personalize their communications: while Podemos shows different political actors (with a clear predominance of Pablo Iglesias and Irene Montero), Vox focuses on their leader, Santiago Abascal.

Analyzing the type of interaction, it is possible to note an enormous majority of information and promotion, that is, unilateral communication, by all the analyzed parties.

As shown in Graph 7, only 5\% of the $P P^{\prime}$ 's posts call for interaction (one challenge), compared with $10 \%$ for Ciudadanos and $20 \%$ for Vox (mainly asking to share the post). Podemos, although $60 \%$ of their messages fall into the category of information/promotion, calls for mobilization in $40 \%$ of the posts.

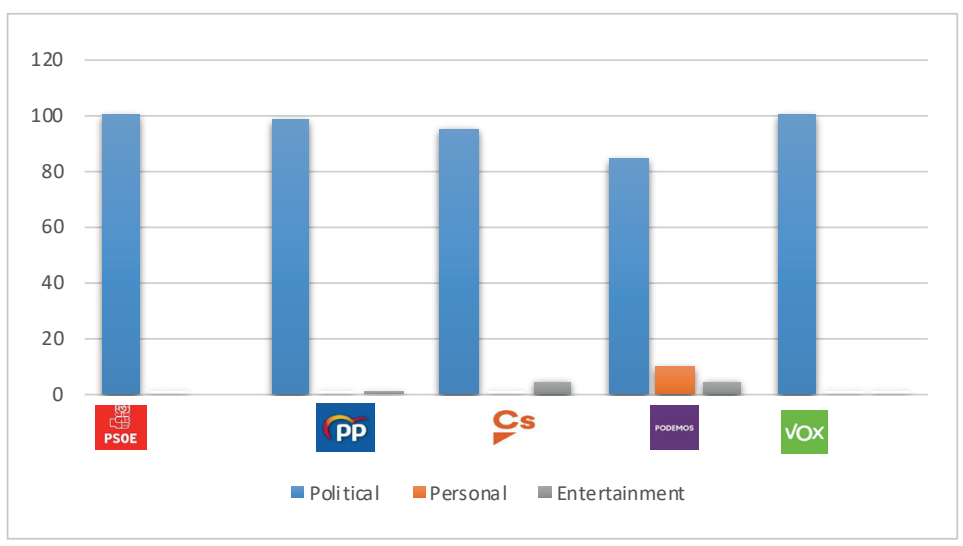

Graph 3. Political, personal, and entertainment content

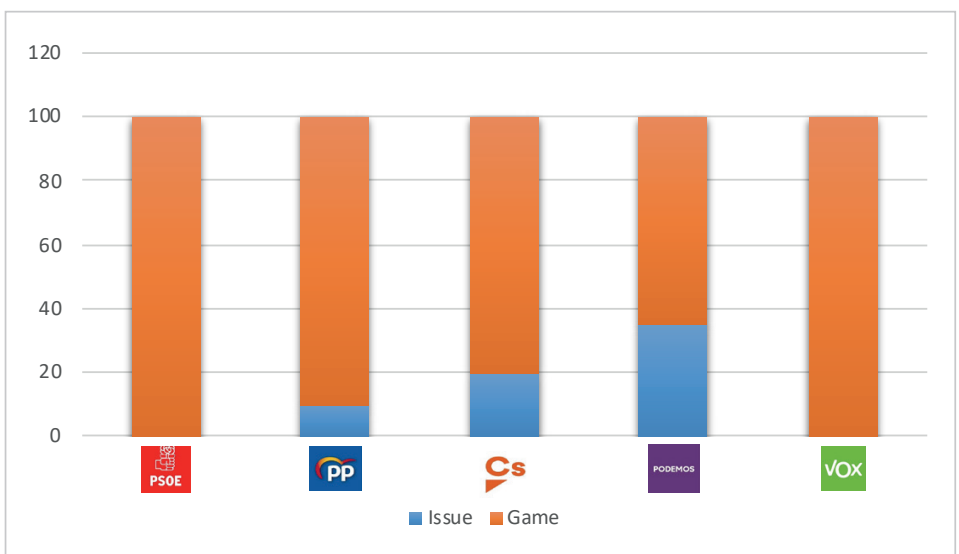

Graph 4. Issue frame and game frame content

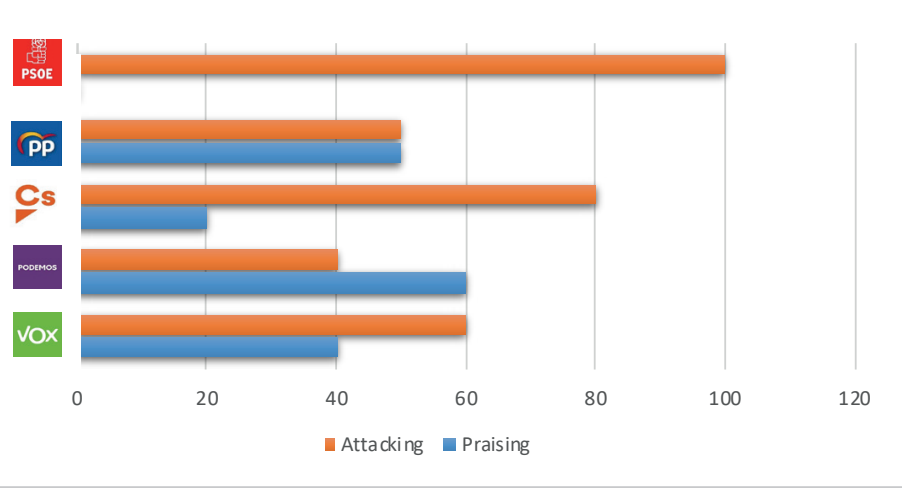

Graph 5. Number of posts attacking adversaries or praising the party

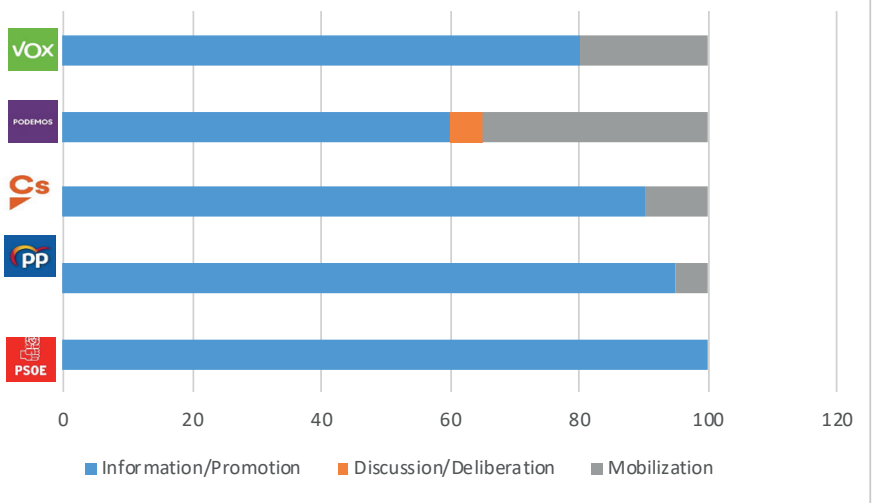

Graph 6. Main functions of the posts 
Interestingly, only Podemos displays a small percentage of messages dedicated to deliberation, indicating that Spanish parties do not see TikTok as a way to stimulate dialog.

\subsection{Engagement}

Social media engagement is measured by the number of interactions, i.e., likes, shares, or comments, of users of a social networking site with a post (Larsson, 2016).

Acknowledging that there are many ways to calculate engagement (Ballesteros-Herencia, 2020) and considering the specific affordances of each platform, we used the following formula proposed by Chen et al. (2021) to calculate engagement for TikTok:

$[($ number of likes + number of comments + number of shares $) /$ number of views $] \times 100$

\begin{tabular}{|c|c|c|c|c|c|c|c|c|c|c|c|}
\hline \multirow{2}{*}{ Party } & \multirow{2}{*}{$\begin{array}{l}\text { Number } \\
\text { of posts }\end{array}$} & \multicolumn{2}{|c|}{ Likes } & \multicolumn{2}{|c|}{ Comments } & \multicolumn{2}{|c|}{ Shares } & \multicolumn{2}{|c|}{ Views } & \multirow{2}{*}{$\begin{array}{c}\text { Number } \\
\text { of fo- } \\
\text { llowers }\end{array}$} & \multirow{2}{*}{$\begin{array}{c}\text { Engage- } \\
\text { ment rate } \\
\%\end{array}$} \\
\hline & & Total & Mean & Total & Mean & Total & Mean & Total & Mean & & \\
\hline PSOE & 1 & 610 & & 0 & & 140 & & 17,800 & & 173 & 4.20 \\
\hline D & 21 & 1,494 & 71.14 & 114 & 5.40 & 187 & 8.9 & 47,019 & 2,239 & 572 & 3.80 \\
\hline & 47 & 8,875 & 188.80 & 974 & 20.70 & 1,623 & 34.50 & 286,696 & 5,674 & 1,185 & 4.00 \\
\hline PODEMOS & 94 & $2,805,168$ & 29,842 & 77,680 & 826.30 & 108,874 & 1,158 & $19,832,500$ & 210,984 & 145,800 & 15.08 \\
\hline & 9 & 112,885 & 12,542 & 14,308 & 1,589 & 18,381 & 2,042 & $1,814,800$ & 201,644 & 25,000 & 8.02 \\
\hline
\end{tabular}

As expected, the party that publishes most and most constantly, Podemos, is also the party with the highest number of followers and views.

Podemos and Ciudadanos are the parties that allocate more time and dedication to TikTok; however, the interactions reveal that Podemos shows the highest engagement rate $(15.08 \%)$, followed by Vox $(8.02 \%)$, while the other parties do not exceed $4 \%$.

Podemos also scores higher in terms of likes, but when it comes to both comments and shares, Vox's mean is almost twice that of Podemos.

In particular, considering the post showing the highest engagement rate reveals how the publications by both Podemos and Vox fit very well with the language of TikTok.

The post by Podemos with the greatest engagement shows its leader twerking, while the post by Vox with the greatest engagement is its first, showing Santiago Abascal interacting with young tiktokers.

The message by Ciudadanos with the greatest engagement, albeit not high, includes the use of a popular hashtag, while the post by the $P P$ with the greatest engagement is the only "challenge" post published.

Although limited, these results seem to suggest that the most engaging posts are those matching the specific genres and affordances of TikTok.

Probably the most interesting feature of TikTok is its algorithmic recommendation system, which is more central to the user experience than on any other platform 


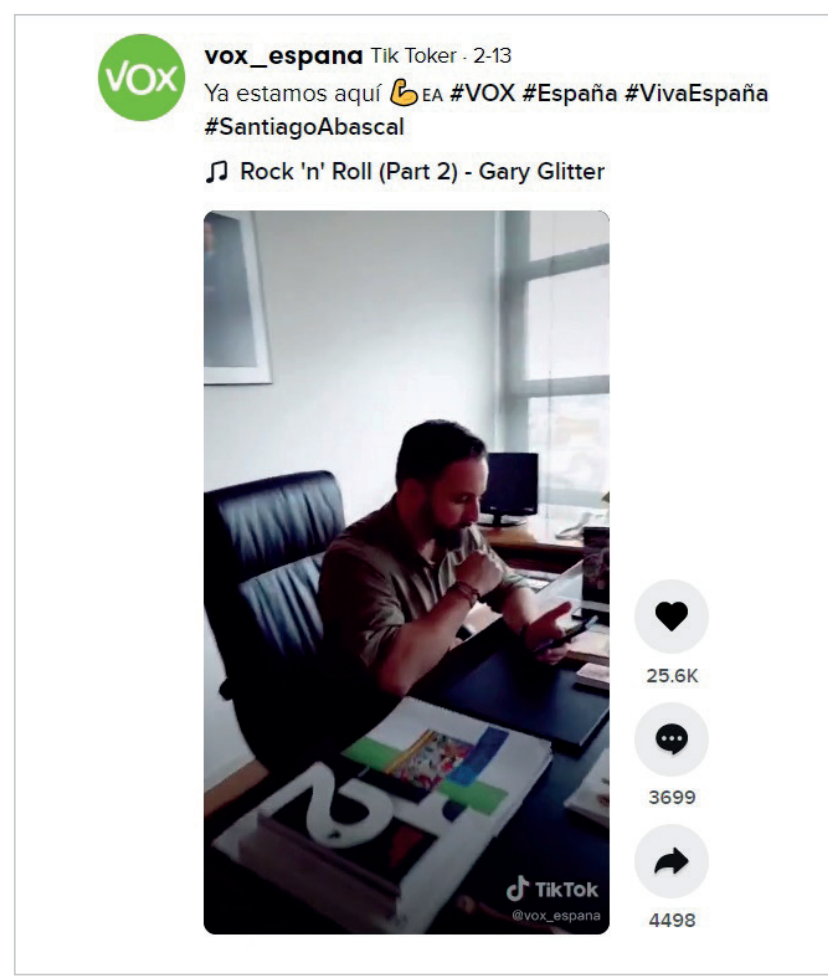

Image 1. Vox's most engaging post

Source: TikTok, 13/2/2020

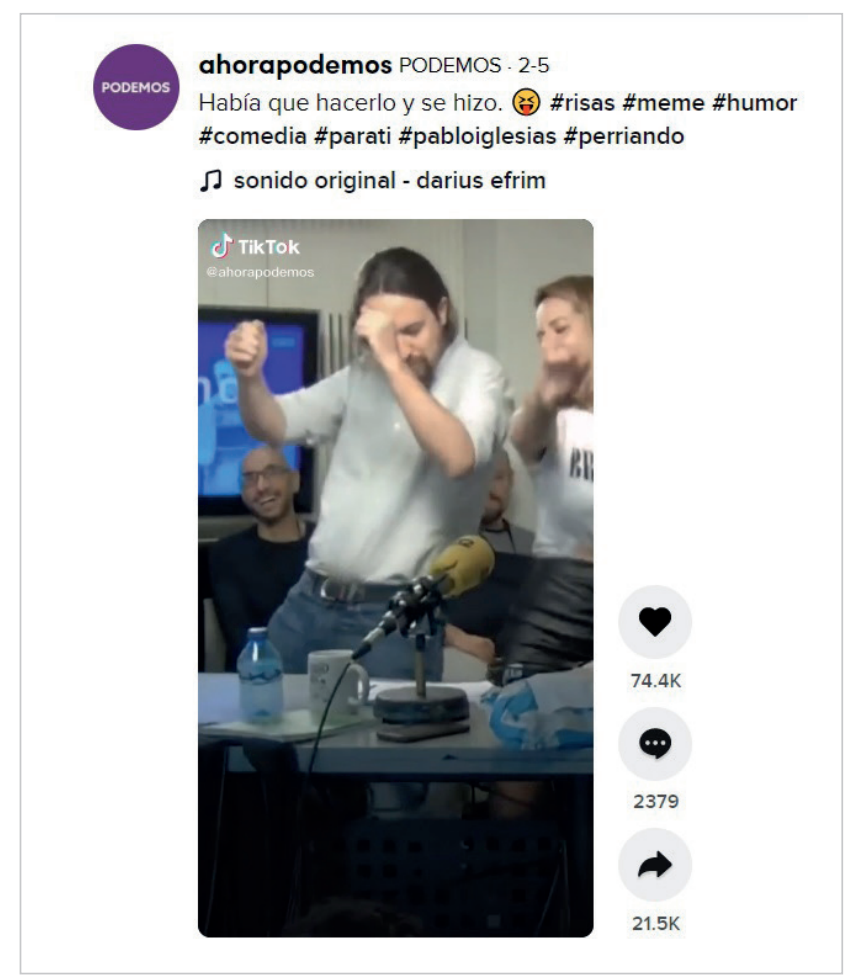

Image 2. Podemos' most engaging post

Source: TikTok, 5/2/2020

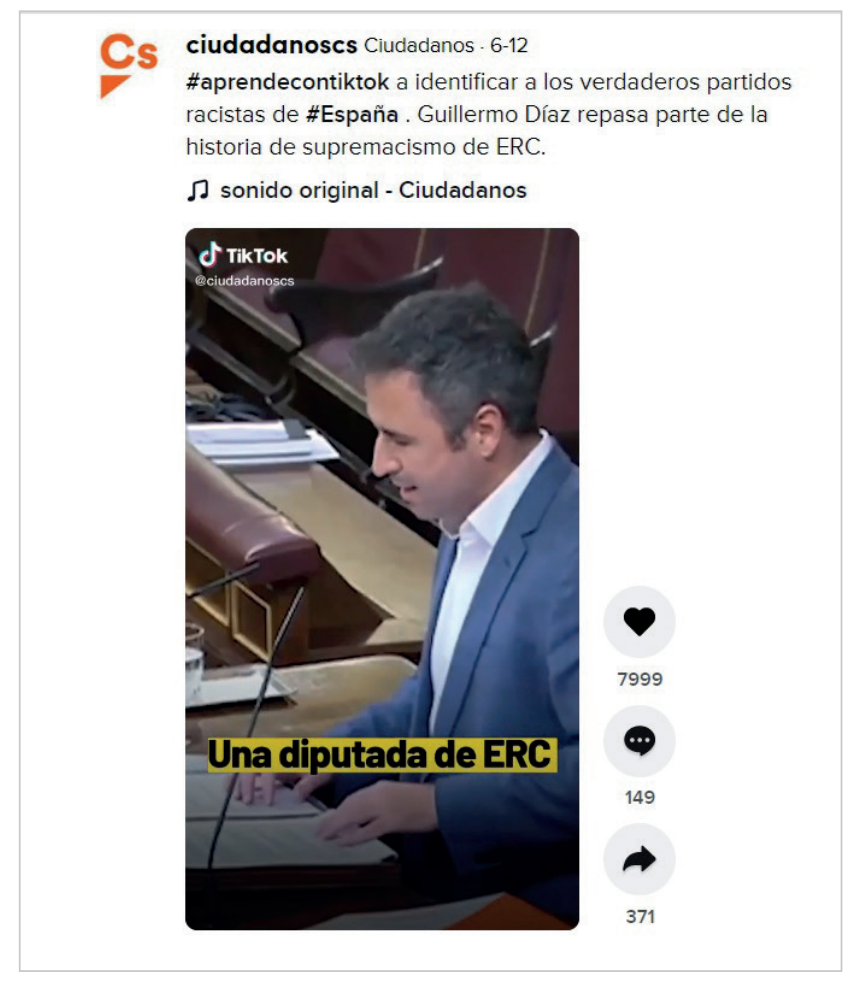

Image 3. The post by Ciudadanos with the highest engagement Source: TikTok, 12/6/2020

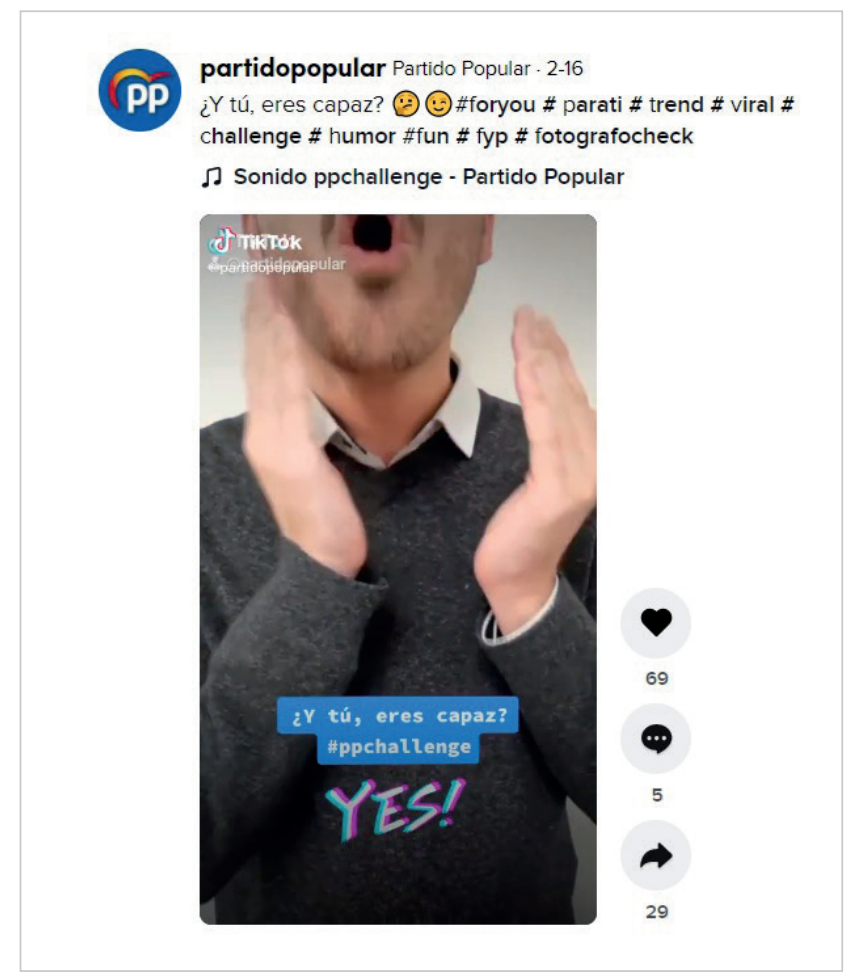

Image 4. The post by the $P P$ with the highest engagement Source: TikTok, 16/2/2020

\section{Conclusions}

This is the first work to systematically study the activity of political parties on TikTok. It thus provides a first overview of the Spanish case, which must be analyzed in greater depth in future work, while also opening the way to further studies on the opportunities that TikTok may provide politicians to communicate beyond Spain.

The findings reveal that all the analyzed Spanish political parties have joined TikTok, thus confirming the first hypothesis. However, the number of posts, the type of content shared, and the type of interaction reveal great differences. 
In terms of time, against all expectations, the $P P$ was the first party to join this platform. However, from a quantitative perspective, Podemos is the party that uses the app most and most constantly, followed by Ciudadanos, $P P, V o x$, and the $P S O E$, the latter of which published only one post. One can thus observe that, Podemos is the only party to use the platform constantly.
The Partido Popular was the first party to join TikTok, in March 2019, followed by Podemos in January 2020, Vox in February, Ciudadanos in March, and the $P S O E$ in June of the same year

One can thus conclude that, in contrast to findings in other contexts, Spanish parties do not seem to have fully adopted TikTok as an integral part of their communication strategy. Whereas other platforms such as Twitter already form an integral part of their communication strategy (Manfredi-Sánchez; Amado-Suárez; Waisbord, 2021), the use of TikTok by the parties is not as constant, confirming that keeping up with new cultural and technological innovations is still unfinished business for most Spanish parties.

The type of content that the parties post also supports this conclusion: all the parties use TikTok almost entirely to publish political content, somehow neglecting the original entertainment function of the app. These results align with the finding of other studies of the behavior of Spanish parties on Facebook and Twitter (Suau-Gomila, 2020; Miquel-Segarra; López-Meri; Viounnikoff-Benet, 2020), which revealed that they do not fully exploit the affordances of social media.

In the same vein and once again contradicting findings from other countries (Vijay; Gekker, 2021), the personal life of political actors is hardly ever presented. Indeed, even Podemos and Vox, which focus on their main political actors and leader, respectively, tend to present them as political figures rather than focusing on their private personae.

Nonetheless, considering the qualitative data, particularly interactions and engagement rates, one can divide TikTok usage into two: Podemos and Vox, and the other parties.

While most parties use TikTok as an "old" medium, i.e., as a unidirectional communication channel, without fully exploiting the participatory potential of the platform, Vox, and particularly Podemos, although still publishing a majority of promotional content, seem to better adapt to the specific affordances of TikTok by fostering interaction and engaging with their followers.

One can thus state that the second hypothesis that parties that are more active on other platforms will also be more active on TikTok and show higher interaction levels is partially fulfilled: while the more consolidated parties do not seem to understand TikTok as a new instrument to foster dialog with citizens, challenger parties try to fully exploit its potential to connect with a younger audience.

In this sense, it is important to underline that, while Vox behaves like what it is, a challenger party, Podemos, although not being a challenger anymore, still maintains intense technology-related activity.

Both this difference between "old" and "new" parties and the fact that Podemos still implements the communication strategy of a challenger party can be explained by the fact that the majority of the supporters of the two opposite populist parties, Vox and Podemos, are young people, while the more established parties appeal more to adult audiences, thus having less interest in this platform.

The current results thus confirm findings from works about the behavior of Spanish parties on other platforms (Turnbull-Dugarte, 2019; Selva-Ruiz; Caro-Castaño, 2017) regarding the level of interactivity and engagement witnessed by Podemos, although contradicting what was shown in the case of Ciudadanos (López-Meri; Marcos-García; Casero-Ripollés, 2017). Indeed, the latter party, despite publishing a certain amount of content, fails to promote both interaction and engagement.

This party, known since its very beginning for putting social media at the center of its communication strategy (López-Meri; Marcos-García; Casero-Ripollés, 2017), fails when it comes to TikTok, using it as a unidirectional medium. This can be interpreted as one of the side effects of the internal crisis that the party was -and still is- experiencing during the analyzed period or interpreted as a general mainstreaming or consolidation of the party that could elicit interest from more adult voters.

Regarding the last hypothesis on populist parties, it is very surprising that, although Podemos is the party that publishes most, Vox only publishes nine times. However, Vox's engagement level is high, extremely so considering their limited number of posts. Therefore, one can conclude that both our specific hypothesis and the broader thesis of the "elective affinity" (Gerbaudo, 2018) between social media and politics are confirmed in this case.

Along these lines, in an overwhelming majority of the cases, politics is represented as a battle or a competition, that is, in the game frame that presents a dichotomous vision of the world, perfectly matching with a populist discourse (Gómez-García et al., 2019).

These findings also result in several original contributions that are applicable beyond Spain, thereby increasing knowledge on the communication functions that TikTok may provide to politicians. 
In particular, the findings suggest that, although Spanish parties are still not fully using all the affordances of TikTok, rather using the platform almost always to talk about politics, inspection of the most engaging posts, such as that showing Pablo Iglesias twerking, reveals that they clearly display the characteristics of pop politics (Mazzoleni; Sfardini, 2009) and politainment (Berrocal-Gonzalo; Campos-Domínguez; Redondo-García, 2014).
Interestingly, only Podemos displays a small percentage of messages dedicated to deliberation, showing that Spanish parties do not see TikTok as a way to stimulate dialog

This means that posts on TikTok seem to be more successful when parties and political actors incorporate styles, narratives, and staging of the world of spectacle and entertainment into their communicative repertoire. Accordingly, considering that present trends in usage rates suggest that the short-video format is the future of social media (Piñeiro-Otero; Martínez-Rolán, 2020), one might expect an increase in politainment. Acknowledging the limitation of exploratory studies, which, as mentioned above, provide a static picture, future studies should follow the evolution of TikTok's usage to confirm this trend.

The current methodology suffers from a further limitation in not considering user comments. Accordingly, scholars and analysts should also focus on the side of users, considering comments and other types of interaction, together with in-depth analysis of user-generated content.

\section{References}

Aalberg, Tori; Strömbäck, Jasper; De-Vreese, Claes H. (2012). "The framing of politics as strategy and game: A review of concepts, operationalizations and key findings". Journalism, v. 2, pp. 162-178.

https://doi.org/10.1177/1464884911427799

Abejón-Mendoza, Paloma; Carrasco-Polaino, Rafael; Garralón, Miguel L. (2019). "Efecto de los post en Facebook de los principales candidatos españoles en las elecciones generales de 2016 sobre la polarización de la sociedad". Historia y comunicación social, v. 24, n. 2, pp. 599-613.

https://doi.org/10.5209/hics.66302

Abuín-Vences, Natalia; García-Rosales, Daniel-Francisco (2020). "Elecciones generales de 2019 en Twitter: eficacia de las estrategias comunicativas y debates televisados como motor del discurso social". El profesional de la información, v. 29, n. 2, e290213.

https://doi.org/10.3145/epi.2020.mar.13

Alonso-Muñoz, Laura; Casero-Ripollés, Andreu (2018). "Political agenda on Twitter during the 2016 Spanish elections: issues, strategies, and users' responses". Communication \& society, v. 3, n. 3, pp. 7-23.

https://doi.org/10.15581/003.31.3.7-23

Anderson, Katie-Elson (2020). "Getting acquainted with social networks and apps: it is time to talk about TikTok". Library hi tech news, v. 37, n. 4, pp. 7-12.

https://doi.org/10.1108/LHTN-01-2020-0001

Baldwin-Philippi, Jessica (2015). Using technology, building democracy. New York: Oxford University Press. ISBN: 9780 190231910

Ballesteros-Herencia, Carlos A. (2020). “La propagación digital del coronavirus: Midiendo el engagement del entretenimiento en la red social emergente TikTok". Revista española de comunicación en salud, Suplemento 1, pp. 171-185. https://doi.org/10.20318/recs.2020.5459

Barrio, Fernando (2021). "Twitch más allá de los videojuegos: periodistas y politicos se abren espacio". El independiente. https://www.elindependiente.com/futuro/gadget/2021/01/27/twitch-mas-alla-de-los-videojuegos-periodistas-ypoliticos-se-abren-espacio

Berrocal-Gonzalo, Salomé; Campos-Domínguez, Eva; Redondo-García, Marta (2014). “Prosumidores mediáticos en la comunicación política: el 'politainment' en YouTube”. Comunicar, v. 22, n. 43, pp. 65-72.

https://doi.org/10.3916/C43-2014-06

Bianchi, Leonardo (2020). "Salvini è il re del cringe su TikTok, ma è pure l'unico politico italiano a stare lì". Vice, 15 gennaio.

https://www.vice.com/it/article/jgem87/salvini-su-tiktok

Bickerton, Christopher J.; Invernizzi-Accetti, Carlo (2018). "'Techno-populism' as a new party family: the case of the Five Star Movement and Podemos". Contemporary Italian politics, v. 2, n. 10, pp. 132-150.

https://doi.org/10.1080/23248823.2018.1472919 
Bimber, Bruce (2014). "Digital media in the Obama campaigns of 2008 and 2012: Adaptation to the personalized political communication environment". Journal of information technology \& politics, v. 11, n. 2, pp. 130-150. https://doi.org/10.1080/19331681.2014.895691

Blumenthal, Sidney (1980). The permanent campaign: Inside the world of elite political operatives. Boston, MA: Beacon Press. ISBN: 9780807032084

Bossetta, Michael (2018). "The digital architectures of social media: Comparing political campaigning on Facebook, Twitter, Instagram, and Snapchat in the 2016 US election". Journalism \& mass communication quarterly, v. 95, n. 2, pp. 471-496.

https://doi.org/10.1177/1077699018763307

Bucher, Taina; Helmond, Anne (2018). "The affordances of social media platforms". In: The SAGE handbook of social media, pp. 233-253. Sage. ISBN: 9781412962292

https://doi.org/10.4135/9781473984066

Casero-Ripollés, Andreu (2018). "Research on political information and social media: Key points and challenges for the future". El profesional de la información, v. 27, n. 5, pp. 964-974.

https://doi.org/10.3145/epi.2018.sep.01

Cervi, Laura (2021). "TikTok and Generation Z". Theatre, dance and performance training, v. 12, n. 2, forthcoming. https://doi.org/10.1080/19443927.2021.1915617

Cervi, Laura (2020). "Exclusionary Populism and Islamophobia: A comparative analysis of Italy and Spain". Religions, v. $11,516$.

https://doi.org/10.3390/rel11100516

Cervi, Laura; Roca-Trenchs, Núria (2018). "El uso de Twitter por parte de los principales candidatos en las campañas electorales para las elecciones generales españolas: 2011 y 2015. ¿Brecha digital y generacional?”. Doxa comunicación, v. 26, pp. 99-126.

http://hdl.handle.net/10637/9459

Cervi, Laura; Roca-Trenchs, Núria (2017a). "Towards an Americanization of political campaigns? The use of Facebook and Twitter for campaigning in Spain, USA and Norway". Anàlisi, n. 56, pp. 87-100.

https://doi.org/10.5565/rev/analisi.3072

Cervi, Laura; Roca-Trenchs, Núria (2017b). “La modernización de la campaña electoral para las elecciones generales de España en 2015. ¿Hacia la americanización?”. Comunicación y hombre, n. 13, pp. 133-150.

https://www.redalyc.org/articulo.oa?id=129449617007

Cesarino, Leticia (2020). "Como vencer uma eleição sem sair de casa: a ascensão do populismo digital no Brasil”. Internet \& sociedade, v. 1, n. 1, pp. 91-120.

https://revista.internetlab.org.br/wp-content/uploads/2020/02/Como-vencer-uma-eleic\%CC\%A7a\%CC\%83o-sem-sairde-casa.pdf

Chadwick, Andrew (2017). The hybrid media system: Politics and power. New York: Oxford University Press. ISBN: 978 0199759477

Chen, Qiang; Min, Chen; Zhang, Wei; Xiaoyue, Ma; Evans, Richard (2021). "Factors driving citizen engagement with government TikTok accounts during the covid-19 pandemic: Model development and analysis". Journal of medical internet reseach, v. 23, n. 2, e21463.

https://doi.org/10.2196/21463

Cid, Guillermo (2020). "'Baja un dedo si eres de derechas'. La oscura guerra política que viven tus hijos en TikTok". El confidencial, 24 junio.

https://www.elconfidencial.com/tecnologia/2020-06-24/tiktok-politica-vox-trump-Podemos-redes-sociales_2649867

Cohen, Jacob (1960). "A coefficient of agreement for nominal scales". Educational and psychological measurement, $\mathrm{v}$. 20, n. 1, pp. 37-46.

https://doi.org/10.1177/001316446002000104

Dekavalla, Marina (2016). "Issue and game frames in the news: Frame-building factors in television coverage of the 2014 Scottish independence referendum". Journalism, v. 19, n. 11, pp. 1588-1607.

https://doi.org/10.1177/1464884916674231

Dimitrova, Daniela V.; Matthes, Jörg (2018). "Social media in political campaigning around the world: Theoretical and methodological challenges". Journalism \& mass communication quarterly, v. 95, n. 2, pp. 333-342.

https://doi.org/10.1177/1077699018770437 
Dolezal, Martin (2015). “Online campaigning by Austrian political candidates: Determinants of using personal websites, Facebook, and Twitter". Policy and internet, v. 7, n. 1, pp. 103-119.

https://doi.org/10.1002/poi3.83

Ekström, Mats; Sveningsson, Malin (2019). "Young people's experiences of political membership: from political parties to Facebook groups". Information, communication \& society, v. 22, n. 2, pp. 155-171.

https://doi.org/10.1080/1369118X.2017.1358294

Enli, Gunn; Naper, Anja Aaheim (2016). “Social media incumbent advantage: Barack Obama's and Mitt Romney's tweets in the 2012 U.S. Presidential election campaign". In: Axel Bruns, Gunn Enli, Eli Skogerb $\varnothing$, Anders-Olof Larsson, Christian Christensen (eds.). The Routledge companion to social media and politics. New York: Routledge, pp. 39-55. ISBN: 9781 138300934

Enli, Gunn; Rosenberg, Linda-Therese (2018). "Trust in the age of social media: Populist politicians seem more authentic". Social media + society, v. 4, n. 1.

https://doi.org/10.1177/2056305118764430

Gainous, Jason; Wagner, Kevin M. (2014). Tweeting to power: The social media revolution in American politics. New York: Oxford University Press. ISBN: 9780199965076

García-Ortega, Carmela; Zugasti-Azagra, Ricardo (2018). “Gestión de la campaña de las elecciones generales de 2016 en las cuentas de Twitter de los candidatos: entre la autorreferencialidad y la hibridación mediática". El profesional de la información, v. 27, n. 6, pp. 1215-1224.

https://doi.org/10.3145/epi.2018.nov.05

Gerbaudo, Paolo (2018). “Social media and populism: An elective affinity?". Media, culture \& society, v. 40, n. 5, pp. 745-753.

https://doi.org/10.1177/0163443718772192

Gómez-García, Salvador; Gil-Torres, Alicia; Carrillo-Vera, José-Agustín; Navarro-Sierra, Nuria (2019). “Constructing Donald Trump: Mobile apps in the political discourse about the President of the United States". Comunicar, n. 59, pp. 49-59. https://doi.org/10.3916/C59-2019-05

Groshek, Jacob; Engelbert, Jiska (2013). “Double differentiation in a cross-national comparison of populist political movements and online media uses in the United States and the Netherland". New media \& society, v. 15, n. 2, pp. $183-202$. https://doi.org/10.1177/1461444812450685

Guinaudeau, Benjamin; Vottax, Fabio; Munger, Kevin (2020). Fifteen seconds of fame: TikTok and the democratization of mobile video on social media. Working paper.

Gutiérrez-Rubí, Antoni; Peytibi, Xavier (2016). Snapchat y política. Transformando la comunicación social. Editorial Bebookness. ISBN: 9788460814009

Hopster, Jeroen (2020). "Mutual affordances: the dynamics between social media and populism”. Media, culture \& society, v. 43, n. 3, pp. 551-560.

https://doi.org/10.1177/0163443720957889

Jivkova-Semova, Dimitrina; Requeijo-Rey, Paula; Padilla-Castillo, Graciela (2017). "Usos y tendencias de Twitter en la campaña a elecciones generales españolas del 20D de 2015: hashtags que fueron trending topic". El profesional de la información, v. 26, n. 5, pp. 824-837.

https://doi.org/10.3145/epi.2017.sep.05

Jungherr, Andreas (2016). "Twitter use in election campaigns: A systematic literature review". Journal of information technology \& politics, v. 13, n. 1, pp. 72-91.

https://doi.org/10.1080/19331681.2015.1132401

Kastrenakes, Jacob (2020). AOC's debut Twitch stream is one of the biggest ever.

https://www.theverge.com/2020/10/20/21526164/aoc-among-us-twitch-debut-top-concurrent-viewers

Kennedy, Melanie (2020). "If the rise of the TikTok dance and e-girl aesthetic has taught us anything, it's that teenage girls rule the internet right now': TikTok celebrity, girls and the coronavirus crisis". European journal of cultural studies, v. 23, n. 6 , pp. $1069-1076$.

https://doi.org/10.1177/1367549420945341

Klinger, Ulrike; Svensson, Jakob (2016) “Network media logic: Some conceptual considerations”. In: Bruns, A.; Enli, G.; Skogerbo, E.; Larsson, A. O.; Christensen, C. (eds.). The Routledge companion to social media and politics. New York, NY: Routledge, pp. 23-38. ISBN: 9781138300934

Koleson, Jenna (2020). "TikTok is on the clock, will democracy stop?”. SLU law journal online, n. 45.

https://scholarship.law.slu.edu/lawjournalonline/45 
Koopmans, Ruud; Statham, Paul (2010). The making of a European public sphere. Media discourse and political contention. Cambridge: Cambridge University Press. ISBN: 9780521138253

Kreiss, Daniel; Lawrence, Regina G.; McGregor, Shannon C. (2018). “In their own words: Political practitioner accounts of candidates, audiences, affordances, genres, and timing in strategic social media use". Political communication, v. 35 , n. 1, pp. 8-31.

https://doi.org/10.1080/10584609.2017.1334727

Larsson, Anders-Olof (2016). “Online, all the time? A quantitative assessment of the permanent campaign on Facebook". New media \& society, v. 18, n. 2, pp. 274-292.

https://doi.org/10.1177/1461444814538798

Lilleker, Darren G.; Vedel, Thierry (2013). "The internet in campaigns and elections”. In: William H. Dutton (ed.), The Oxford handbook of internet studies, pp. 401-420. Oxford: Oxford University Press. ISBN: 9780199589074

Literat, Ioana; Kligler-Vilenchik, Neta (2019). "Youth collective political expression on social media: The role of affordances and memetic dimensions for voicing political views". New media \& society, v. 21, n. 9, pp. 1988-2009.

https://doi.org/10.1177/1461444819837571

López-Meri, Amparo; Marcos-García, Silvia; Casero-Ripollés, Andreu (2020). “Estrategias comunicativas en Facebook: personalización y construcción de comunidad en las elecciones de 2016 en España". Doxa comunicación, n. 30, pp. 229248.

https://doi.org/10.31921/doxacom.n30a12

López-Meri, Amparo; Marcos-García, Silvia; Casero-Ripollés, Andreu (2017). "What do politicians do on Twitter? Functions and communication strategies in the Spanish electoral campaign of 2016". El profesional de la información, v. 26, n. 5, pp. 795-804.

https://doi.org/10.3145/epi.2017.sep.02

Manfredi-Sánchez, Juan-Luis; Amado-Suárez, Adriana; Waisbord, Silvio (2021). "Presidential Twitter in the face of Covid-19: Between populism and pop politics". Comunicar, n. 66, pp. 83-94.

https://doi.org/10.3916/C66-2021-07

Mazzoleni, Gianpietro; Sfardini, Anna (2009): Politica pop. Da 'porta a porta' a 'L'isola dei famosi'. Bologna: II Mulino. ISBN: 9788815132734

Medina-Serrano, Juan-Carlos; Papakyriakopoulos, Orestis; Hegelich, Simon (2020). "Dancing to the partisan beat: A first analysis of political communication on TikTok". In: $12^{\text {th }}$ ACM Conference on web science, July 7-10, Southampton, UK. ACM, New York, NY, USA.

Metz, Manon; Kruikemeier, Sanne; Lecheler, Sophie (2020). “Personalization of politics on Facebook: examining the content and effects of professional, emotional and private self-personalization". Information, communication \& society, v. 23, n. 10 , pp. $1481-1498$.

https://doi.org/10.1080/1369118X.2019.1581244

Miquel-Segarra, Susana; López-Meri, Amparo; Viounnikoff-Benet, Nadia (2020). "Engagement entre políticos y seguidores en Facebook. El caso de las elecciones generales de 2016 en España”. Obra digital, n. 19, pp. 61-79.

https://doi.org/10.25029/od.2020.251.19

Mirchandani, Maya (2020). “Populisme, propagande et politique: les réseaux sociaux au cœur de la stratégie électorale de Narendra Modi". Hérodote, n. 177-178, pp. 59-76.

https://doi.org/10.3917/her.177.0059

Moeller, Judith; De-Vreese, Claes; Esser, Frank; Kunz, Ruth (2014). "Pathway to political participation: The influence of online and offline news media on internal efficacy and turnout of first-time voters". American behavioral scientist, v. 58, n. 5, pp. 689-700.

https://doi.org/10.1177/0002764213515220

Nahon, Karine (2016). "Where there is social media there is politics". In: Bruns, Axel; Enli, Gunn; Skogerbö, E.; Larsson, Anders; Christensen, Christian (eds.). Routledge companion to social media and politics. New York: Routledge, pp. 39-55. ISBN: 9781138300934

O'Connor, Cliodhna; Joffe, Helene (2020). "Intercoder reliability in qualitative research: debates and practical guidelines". International journal of qualitative methods, v. 19, online first.

https://doi.org/10.1177/1609406919899220

Omnicore (2020). TikTok by the numbers: Stats, demographics \& fun facts. Omnicore, 12 February. https://www.omnicoreagency.com/tiktok-statistics 
Papacharissi, Zizi (2015). Affective publics: Sentiment, technology, and politics. Oxford: Oxford University Press. ISBN: 9780199999743

Pineda, Antonio; Bellido-Pérez Elena; Barragán-Romero, Ana (2020). "Backstage moments during the campaign: The interactive use of Instagram by Spanish political leaders". New media \& society, online first.

https://doi.org/10.1177/1461444820972390

Piñeiro-Otero, Teresa; Martínez-Rolán, Xabier (2020). "Para comprender la política digital - Principios y acciones". Vivat academia, n. 152, pp. 19-48.

https://doi.org/10.15178/va.2020.152.19-48

Quinlan, Stephen; Gummer, Tobias; Roßmann, Joss; Wolf, Christof (2018). "Show me the money and the party! - Variation in Facebook and Twitter adoption by politicians" Information, communication \& society, v. 21, n. 8, pp. $1031-1049$. https://doi.org/10.1080/1369118X.2017.1301521

Rahat, Gideon; Sheafer, Tamir (2007). "The personalization (s) of politics: Israel, 1949-2003". Political communication, v. 24, n. 1 , pp. $65-80$. https://doi.org/10.1080/10584600601128739

Ramírez-Gil, Marta; Gómez-de-Travesedo-Rojas, Ruth (2020). “Gestión de la política española en YouTube: Una asignatura pendiente". Observatorio, v. 14, n. 1, pp. 22-44.

http://obs.obercom.pt/index.php/obs/article/view/1491

Sampietro, Agnese; Sánchez-Castillo, Sebastián (2020). "Building a political image on Instagram: A study of the personal profile of Santiago Abascal (Vox) in 2018". Communication \& society, v. 33, n. 1, pp. 169-184.

https://doi.org/10.15581/003.33.1.169-184

Selva-Ruiz, David; Caro-Castaño, Lucía (2017). “Uso de Instagram como medio de comunicación política por parte de los diputados españoles: la estrategia de humanización en la "vieja" y la "nueva" política". El profesional de la información, v. 26 , n. 5, pp. 903-915.

https://doi.org/10.3145/epi.2017.sep.12

Simpson, Ellen; Semaan, Bryan (2021). "'For you, or for you'? Everyday LGBTQ+ encounters with TikTok". Proceedings of the ACM on human-computer interaction 4, CSCW3, pp. 1-34.

https://dl.acm.org/toc/pacmhci/2021/4/CSCW3

Stier, Sebastian; Bleier, Arnim; Lietz, Haiko; Strohmaier, Markus (2018). “Election campaigning on social media: Politicians, audiences, and the mediation of political communication on Facebook and Twitter". Political communication, $\mathrm{v}$. 35, n. 1, pp. 50-74.

https://doi.org/10.1080/10584609.2017.1334728

Suau-Gomila, Guillem (2020). "Microblogging electoral: la estrategia comunicativa de Podemos y Ciudadanos en Twitter en las campañas electorales del 20D y el 26J". Prisma social, n. 28, pp. 103-126.

https://revistaprismasocial.es/article/view/3389

Suau-Gomila, Guillem; Pont-Sorribes, Carles (2019). "Microblogging electoral: los usos de Twitter de Podemos y Ciudadanos y sus líderes Pablo Iglesias y Albert Rivera en las elecciones generales españolas de 2016". Estudios sobre el mensaje periodístico, v. 25, n. 2, pp. 1121-1139.

https://doi.org/10.5209/esmp.64829

Turnbull-Dugarte, Stuart J. (2019). "Selfies, policies, or votes? Political party use of Instagram in the 2015 and 2016 Spanish general elections". Social media + society, v. 5, n. 2.

https://doi.org/10.1177/2056305119826129

Van-Aelst, Peter; Sheafer, Tamir; Stanyer, James (2012). "The personalization of mediated political communication: A review of concepts, operationalizations and key findings". Journalism, v. 13, n. 2, pp. 203-220.

https://doi.org/10.1177/1464884911427802

Van-Dijck, José; Poell, Thomas (2013). “Understanding social media logic". Media and communication, v. 1, n. 1, pp. 2-14.

https://doi.org/10.17645/mac.v1i1.70

Vasko; Vidar; Trilling, Damian (2019). "A permanent campaign? Tweeting differences among members of Congress between campaign and routine periods". Journal of information technology \& politics, v. 16, n. 4, pp. 342-359.

https://doi.org/10.1080/19331681.2019.1657046

Vergeer, Maurice; Hermans, Liesbeth; Cunha, Carlos (2013). "Web campaigning in the 2009 European Parliament elections: A cross-national comparative analysis". New media and society, v. 15, n. 1, pp. 128-148.

https://doi.org/10.1177/1461444812457337 
Vergeer, Maurice; Hermans, Liesbeth; Sams, Steven (2013). “Online social networks and micro-blogging in political campaigning: The exploration of a new campaign tool and a new campaign style". Party politics, v. 19, n. 3, pp. 477-501. https://doi.org/10.1177/1354068811407580

Vijay, Darsana; Gekker, Alex (2021). "Playing politics: How Sabarimala played out on TikTok". American behavioral scientist, v. 65, n. 5, pp. 712-734.

https://doi.org/10.1177/0002764221989769

Zarouali, Brahim; Dobber, Tom; De-Pauw, Guy; De-Vreese, Claes (2020). "Using a personality-profiling algorithm to investigate political microtargeting: Assessing the persuasion effects of personality-tailored ads on social media". Communication research, online first.

https://doi.org/10.1177/0093650220961965

Zheng, Yingqin; Yu, Ai (2016). "Affordances of social media in collective action: the case of Free Lunch for Children in China". Information systems journal, v. 26, pp. 289-313.

https://doi.org/10.1111/isj.12096

Zhu, Yumei (2020). "The expectation of TikTok in international media: A critical discourse analysis". Open journal of social sciences, v. 8, pp. 136-148.

https://doi.org/10.4236/jss.2020.812012

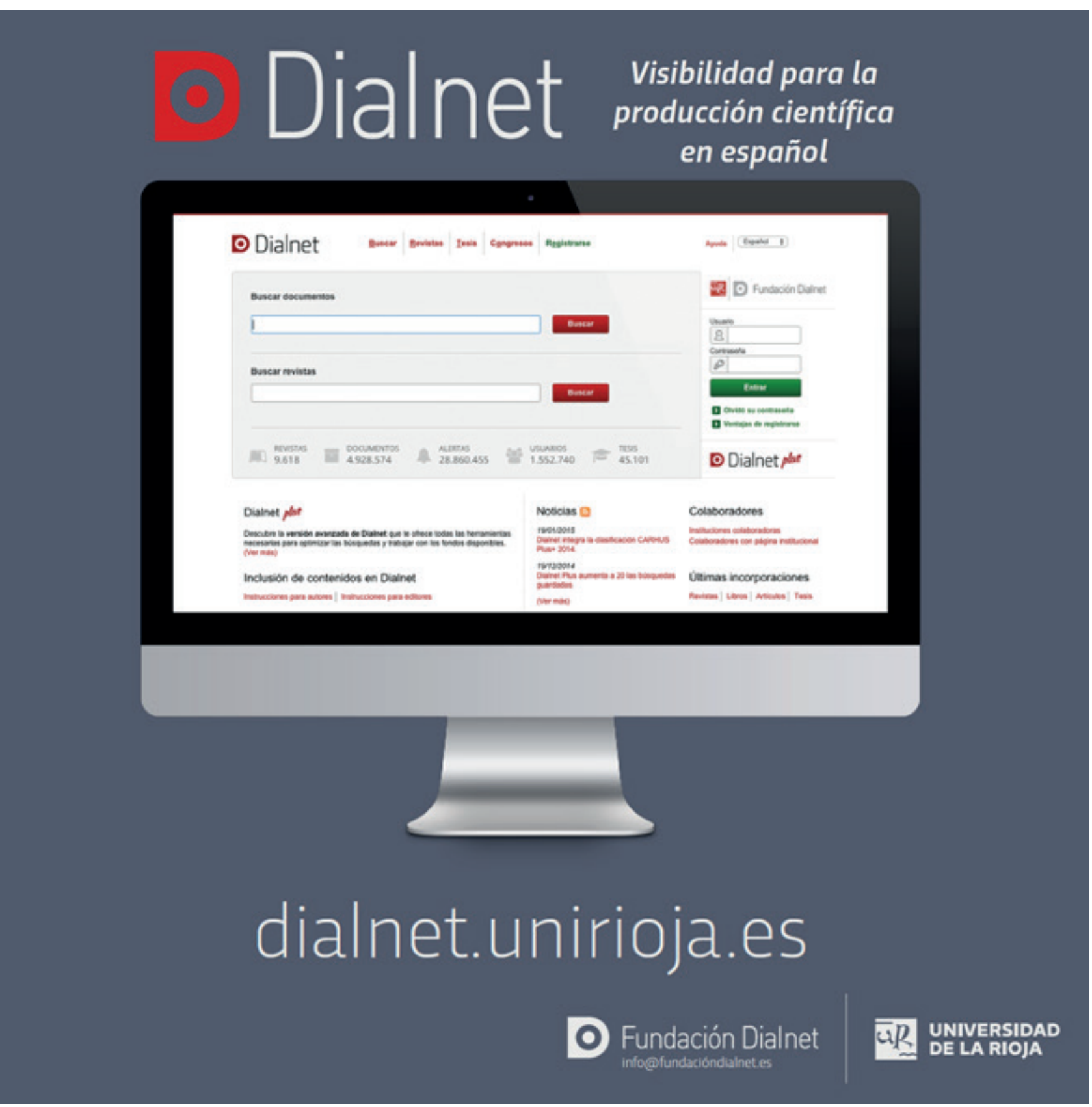

